\title{
Maxim Fionin \\ Greek Manuscript D-227 \\ from the Collection of IOM, RAS. An Archeographical Analysis
}

\begin{abstract}
This paper deals with an archeographical analysis of the Greek minuscule manuscript D-227 kept in the collection of the IOM, RAS. The author reviews its present condition and deciphers the inscriptions left on its binding by the staff of the Winter Palace Imperial Library when it was delivered there and notes made by the staff of the Asiatic Museum (forerunner of the IOM). The contents of the parts are established, as is, wherever possible, their numbering. Inscriptions in Greek, including one written by Hierotheos, Patriarch of Antioch (1850-1885), are deciphered and translated. Key words: Greek lectionary, minuscule manuscript, IOM manuscript collection, collection of Gregory IV, Arab Christian manuscripts, parchment codex
\end{abstract}

The Greek lectionary D-227 (as designated by the Asiatic Museum) was among the Arab Christian manuscripts presented by Patriarch of Antioch Gregory IV to Emperor Nicholas II in 1913, the year when the Romanov dynasty celebrated its 300th anniversary. In February 1919, the entire collection was transferred to the Asiatic Museum.

The manuscripts were transferred from the Winter Palace with the active involvement of academician Ignaty Yulianovich Krachkovsky. ${ }^{1}$ In one of his studies he remarked that Prof. Grigol Tsereteli had dated lectionary D-227 to the 11 th $\mathrm{c}^{2}$

Since the mid-20th c. the manuscript has hardly been mentioned in scholarly literature, but the lectionary was notably included in the catalog by Kurt Aland et al. and in another by E.E. Granstroem, listing Greek manuscripts kept in Leningrad libraries. ${ }^{3}$ To my mind, the manuscript deserved more

(C) Maxim Vladimirovich Fionin, Institute of Oriental Manuscripts, Russian Academy of Sciences

${ }^{1}$ KRACHKOVSKY 1946, 31-37.

${ }^{2}$ KRACHKOVSKY 1960, vol. 6, 429.

${ }^{3}$ In the former the lectionary from the IOM, RAS collection was designated as $l 1847$; provided was also the information concerning the place where it was stored (ALAND 1994, 331).

Granstroem provided more data, including a brief review of the contents, size, and ruling. Besides, that catalog contained decipherings of a few Greek inscriptions on its fly-leaf (GRANSTROEM 1961, 228). 
close attention as its Gospel parts reveal certain peculiarities that are possibly characteristic of the ritual observed by the Antioch Church.

Manuscript D-227 is a well-preserved parchment codex. Its wooden binding is covered with leather. On its spine, there is a band woven of yellow, green, white, and brown silk threads.

The thick parchment folios are of good quality, their inner and outer sides are almost impossible to distinguish; however, a few have developed cracks and holes. The uneven surface of the parchment proves that the manuscript was once stored in a humid environment.

The missing wooden backboard of the binding has been replaced with thick cardboard inserted into the leather cover during restoration. Additionally, the restorers made good the damaged parts of the leather with leatherette. Both flyleaves were also reinforced with pasted-on sheets of cigarette paper (ff. 01, 001).

Certain folios $(252-256,277-308)$ have been damaged by "pink mould", especially ff. 305-308 where the text is next to illegible. When the manuscript was restored at the Asiatic Museum, ff. 305-308 were supplemented with paper glued onto them so that the size of the codex remained unaffected. Ff. 1-9, 278-280 have been damaged with lamp oil, making the text impossible to read. On the paper filling present on f. 1 there is an Arabic inscription attesting to the fact that the manuscript had been restored previously, possibly in the 19th c. Folio 277 is cut in the middle, with half of it missing.

The entire manuscript contains $308 \mathrm{ff}$; medieval restorers may have inserted the three paper ones (ff. $80,82,83$ ). It should be noted that two of the three display water marks: f. 80 bears three small circles resembling a clover leaf and the Latin letters $b$ and $v$; f. 82 has three crescents in the middle.

According to E.E. Granstroem, the ruling corresponds to type I, $17 \mathrm{a},{ }^{4}$ but that might well be a typographical error, as lectionary D-227 displays the features characteristic of type II, 17a, as one can easily see that there were two columns intended for text instead of just one as in I, 17a. ${ }^{5}$

The text is written in two columns; the number of lines varies between 22 and 25, but most folios are ruled for 24 .

The basic text is written in black ink; the entire Greek text is provided with diacretic markings in cinnabar. The same cinnabar, frequently with gold, served for special ritualistic instructions and headings, e.g. TH̃ Ẽ THC $\tilde{\mathrm{B}} \mathrm{EB} \Delta$ or '́k $\tau[0 \hat{]}] \kappa \alpha \tau[\grave{\alpha}] \mathrm{I} \omega\left[\alpha^{\prime} \nu \nu \eta \nu\right]$. Virtually every pericope starts with a multicolored initial letter; that prompts the assumption that an artist worked on the manuscript as well as the scribe.

\footnotetext{
${ }^{4}$ GRANSTROEM 1961, 228.

${ }^{5}$ LAKE 1934, pl. 5.
} 
Almost the entire text of the manuscript, except some ritualistic instructions, is written in minuscule lettering; the hand is experienced, the characters are not slanted, a lot of them look rounded.

The size of the manuscript is 31.5 by $21.0 \mathrm{~cm}$ (12.4" by 8.3 ").

The manuscript is made up of 43 gatherings, most containing $8 \mathrm{ff}$., but as the whole has been restored more than once, some differ from the others in that respect. The folios in some gatherings carry numbers in the bottom right-hand corner, written in black, mainly lower case, but with the occasional capital. Below is a table indicating the number of folios in every gathering of the codex:

\begin{tabular}{|c|c|c|}
\hline Gathering & $\begin{array}{c}\text { Quantity of folia } \\
\text { in each quire } \\
\text { of codex }\end{array}$ & Remarks \\
\hline fly-leaf & $01-04$ & \\
\hline 1 & III-III & \\
\hline 2 & $\mathrm{~V}-\mathrm{V}$ & $\begin{array}{l}\text { The gathering displays traces of restoration, a few } \\
\text { pasted-on folios }\end{array}$ \\
\hline 3 & III-IV & One pasted-on folio \\
\hline 4 & IV-IV & \\
\hline 5 & IV-IV & $\begin{array}{l}\text { The first instance of a number in the bottom } \\
\text { right-hand corner of f. } 32: \tilde{E}\end{array}$ \\
\hline 6 & IV-IV & \\
\hline 7 & IV-IV & \\
\hline 8 & IV-IV & \\
\hline 9 & IV-IV & f. 64 bears traces of cut-off numbering \\
\hline 10 & IV-IV & $\begin{array}{l}\text { The bottom right-hand corner of f. } 72 \text { displays } \\
\text { the gathering number: } \ddot{I}\end{array}$ \\
\hline 11 & I-III & $\begin{array}{l}\text { The gathering contains inserted and pasted paper } \\
\text { ff. } 80,82,83\end{array}$ \\
\hline 12 & $\mathrm{IV}-\mathrm{V}$ & $\begin{array}{l}\text { F. } 64 \text { bears traces of a gathering number; one pasted } \\
\text { folio (f. } 92 \text { ) with traces of cut-off numbering }\end{array}$ \\
\hline 13 & III-V & Two pasted-on folios \\
\hline 14 & II-III & One pasted-on folio \\
\hline 15 & IV-IV & F. 106 bears traces of cut-off gathering numbering \\
\hline 16 & IV-IV & F. 114 displays the gathering number: IZ̃ \\
\hline 17 & IV-IV & F. 122 displays the gathering number: IŨ \\
\hline 18 & III-III & $\begin{array}{l}\text { F. } 128 \text { displays the gathering number: } \mathrm{I} \tilde{\Theta} \text {, its edge is } \\
\text { missing }\end{array}$ \\
\hline 19 & IV-IV & F. 136 displays the gathering number: $\tilde{\mathrm{K}}$ \\
\hline
\end{tabular}




\begin{tabular}{|c|c|c|}
\hline Gathering & $\begin{array}{l}\text { Quantity of folia } \\
\text { in each quire } \\
\text { of codex }\end{array}$ & Remarks \\
\hline 20 & IV-IV & F. 144 displays the gathering number: $\kappa \tilde{\alpha}$ \\
\hline 21 & IV-IV & \\
\hline 22 & IV-IV & \\
\hline 23 & IV-IV & $\begin{array}{l}\text { F. } 168 \text { bears undecipherable traces of gathering } \\
\text { numbering }\end{array}$ \\
\hline 24 & IV-I & $\begin{array}{l}\text { F. } 176 \text { bears undecipherable traces of gathering } \\
\text { numbering; there are traces of cut-away folios }\end{array}$ \\
\hline 25 & IV-IV & $\begin{array}{l}\text { F. } 181 \text { bears traces of gathering numbering, but only } \\
\text { the character } \tilde{\kappa} \text { is decipherable }\end{array}$ \\
\hline 26 & IV-IV & \\
\hline 27 & IV-IV & \\
\hline 28 & IV-IV & \\
\hline 29 & IV-IV & F. 213 displays the gathering number: $\tilde{\Lambda}$ \\
\hline 30 & IV-IV & \\
\hline 31 & IV-IV & $\begin{array}{l}\text { F. } 229 \text { bears traces of gathering numbering, but only } \\
\text { character } \tilde{\Lambda} \text { is decipherable, the rest is cut off }\end{array}$ \\
\hline 32 & IV-IV & \\
\hline 33 & IV-IV & F. 245 displays the gathering number: $\Lambda \tilde{\Delta}$ \\
\hline 34 & III-IV & $\begin{array}{l}\text { F. } 253 \text { bears traces of a gathering number, but only } \\
\text { the tilde } \sim \text { is left }\end{array}$ \\
\hline 35 & IV-IV & $\begin{array}{l}\text { F. } 260 \text { bears character } \tilde{\Lambda} \text {, the only trace of a } \\
\text { gathering number }\end{array}$ \\
\hline 36 & IV-IV & $\begin{array}{l}\text { F. } 268 \text { bears character } \tilde{\Lambda} \text {, the only trace of a } \\
\text { gathering number }\end{array}$ \\
\hline 37 & I-I & $\begin{array}{l}\text { F. } 276 \text { displays the gathering number: } \Lambda \tilde{H} ; \text { f. } 277 \text { is } \\
\text { cut across its middle }\end{array}$ \\
\hline 38 & III-III & \\
\hline 39 & III-III & \\
\hline 40 & II-II & \\
\hline 41 & III-IV & $\begin{array}{l}\text { F. } 253 \text { bears traces of a gathering number, but only } \\
\text { a fragment of the tilde is left }\end{array}$ \\
\hline 42 & II-II & \\
\hline 43 & II-II & \\
\hline $\begin{array}{l}\text { rear } \\
\text { fly-leaf }\end{array}$ & 001 & \\
\hline
\end{tabular}




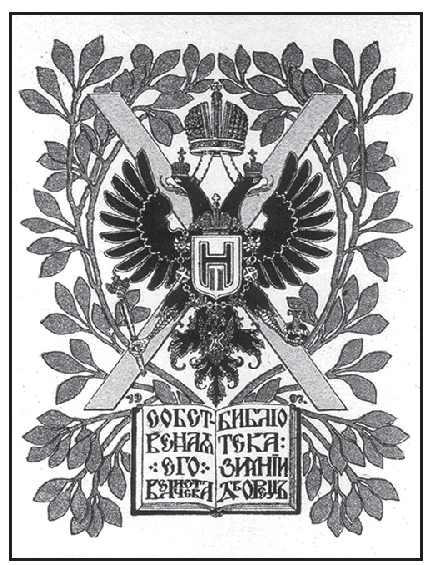

Pl. 1. A bookplate designed by Armin, Baron von Fölkersahm

The front of the binding bears a pasted-on card carrying the following text in Russian: "4 Gospels in Greek written on 308 parchment folios. The book was donated to the Cathedral of St. Sergius, Bacchus [and] Levandius in Bosra in the year 6864/A.D. 1356, and renovated in 1418 by Patriarch Joachim".

Below, the same card carries another inscription in black ink:

"Presented by Gregory, Patriarch of Antioch, to His Imperial Majesty on the occasion of the 300th anniversary of the Romanov dynasty". Both inscriptions must have been made when the manuscript arrived in the Library of the Winter Palace.

The left fly-leaf bears a bookplate designed by Armin, Baron von Fölkersahm, Director of the Hermitage, featuring the imperial coat of arms and Nicholas II's monogram. The text reads: "His Majesty's Own Library, the Winter Palace".

F. 02 bears a well-preserved inscription written in lead pencil and reading: "Inventory No. 268. March 13, 1913, from His Majesty's room". 6

Below, there is a later stamp of the Asiatic Museum: "The Asiatic Museum. Ms.or. D. 227, U.S.S.R. Academy of Sciences" [Азиатский музей. Ms.or. D. 227 Академии наук CCCP].

The last pages of the manuscript were written on in Arabic (ff. $307 \mathrm{v}$ and 308). More texts in Arabic can be found on ff. 03, 04, 04v, 1, 46v, 108v,

\footnotetext{
${ }^{6}$ Evidently, written when the manuscript was sent to the Library of the Winter Palace from the Tsar's private premises.
} 
256, 263, 267, 270v, 279, 285v, 288, 292, 293v, 297 (cut off), 297v, 304v, $306{ }^{7}$

On ff. 04 and 304v there are a few inscriptions in Greek; f. 04 has two, written in black. The first, placed at the very top of the page, was written in a very sophisticated manner which certainly interferes with its deciphering:

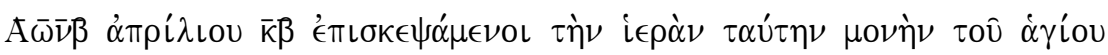

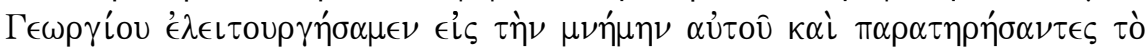

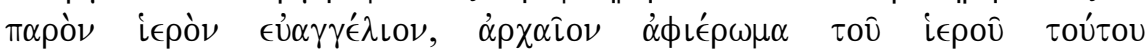

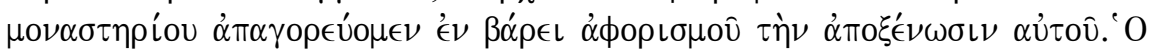

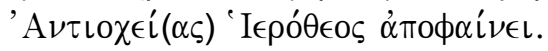

"April 22, 1852, during our visit to the holy monastery of St. George we served a [holy] mass in George's memory, and, having noticed this present holy Gospel, an ancient donation to this holy monastery, we prohibited its removal under the threat of excommunication. Hierotheos, Patriarch of Antioch, so declared".

The author of this text was evidently Hierotheos, Patriarch of Antioch from October 19, 1850 to March 25, 1885. Before that, he had been Archbishop of Tabor and in 1833-1838 he represented the Patriarchate of Jerusalem in Russia. ${ }^{8}$

Below, there is another inscription in a different hand:

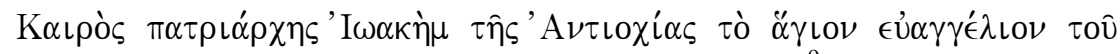

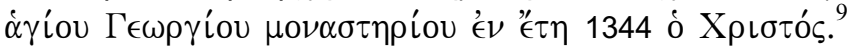

"Dating from the reign of Patriarch Joachim, a Holy Gospel from the St. George Monastery, year 1344 [after] Christ". ${ }^{10}$

\footnotetext{
${ }^{7}$ Regretfully, the Arabic inscriptions have so far not been studied, but at a later point in the research they are to be translated and commented upon.

${ }^{8}$ Lisovoy, SMirNOVA 2009, 10-11.

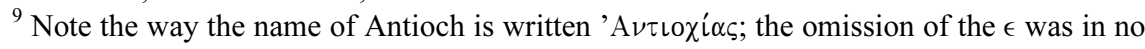
way a mistake. This was aan alternative spelling of the toponym. We cannot be sure about the authorship of these lines, but as they are placed below Patriarch Hierotheos's note they must have been written later than 1852. Also remarkable is the fact that the Patriarch used the more

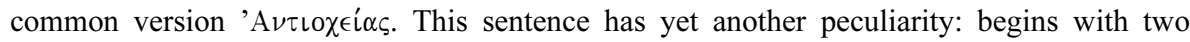

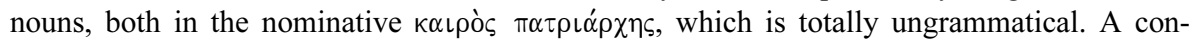

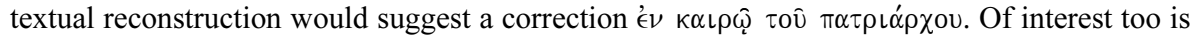
the fact that the note contains a date written in Arabic numerals instead of Greek. That question looks like requiring a separate study.

${ }^{10}$ In this case, the translation renders only the sense of the phrase, as its literal translation is impossible.
} 
I.Yu. Krachkovsky believed that the manuscript was renovated in the 15th c., during the incumbency of Joachim II as Patriarch of Antioch (14111426), but that assumption contradicts the date of $1344 .{ }^{1}$

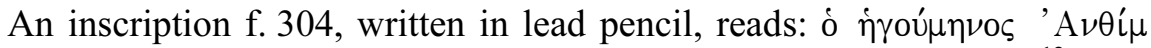
$i \in \rho \circ \mu$. "ॄo 1866. ("The Abbot Anthimus, hieromonk. Year of 1866"). ${ }^{12}$

So far, all attempts to identify the author of this inscription have remained unsuccessful.

Further study of the manuscript will require a better knowledge of the circumstances surrounding Gregory IV's visit to St. Petersburg. It will also be necessary to study the structure of the lectionary in more detail, along with the specifics of its text. Attempts should be made to identify possible differences between it and the main group of the 11th-14th cc. Greek lectionaries.

\section{References}

GRANSTROEM E.E. 1961: "Katalog grecheskikh rukopisei Leningradskikh khranilisch, vyp. 3. Rukopisi XI v." [Catalog of the Greek manuscripts stored in Leningrad collections. Issue 3. Manuscripts of the 11th c.]. Vizantiiskii vremennik 19. Moscow: Nauka, 216-243.

KRACHKOVSKY I.Yu. 1960: “Arabskie rukopisi iz sobrania Grigoriia IV, Patriarkha Antiokhiiskogo. (Kratkaia opis) [Arabic manuscripts from the collection of Gregory IV, Patriarch of Antioch. (A brief description)]". Izbrannye sochineniia [Selected works], vol. 6 . Moscow-Leningrad: Izdatel'stvo Akademii Nauk of the USSR, 423-454.

KrachKovsky I.Yu. 1946: Nad arabskimi rukopisiami. [Poring over Arabic manuscripts]. Moscow-Leningrad: Izdatel'stvo Akademii Nauk of the USSR.

Lisovoy N.N. and SMIRNOVA I.Yu. 2009: "Uchastie russkikh diplomatov v tserkovnopoliticheskoi zhizni vostochnykh patriarkhatov v seredine XIX veka" [Participation by Russian diplomats in the ecclesiastical and political life of the Oriental patriarchates in the mid. 19th c.]. Rossiiskaia istoriia 1, 5-25.

Aland, Kurt and Welte, Michael and Köster, Beate and JunACK, Klaus 1994: Kurzgefasste Liste der griechischen Handschriften des Neuen Testaments. Berlin-New York: Walter de Gruyter.

LaKe, Kirsopp and LaKe, Silva 1934: Dated Greek Minuscule Manuscripts to the Year 1200, vol. I. Boston: The American Academy of Arts and Sciences.

\footnotetext{
${ }^{11}$ KRACHKOVSKY 1960, 429

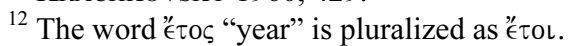

